\title{
Effect of Cold Storage on Post Storage Life of Gerbera (Gerbera jamesonii) Cut Flowers at Ambient Conditions
}

\author{
Mansute Ajinkya*, P.B. Jadhav, D.B. More and K.P. Pokharkar
}

Ecofrost Technologies Pvt. Ltd., Survey No 134/1, 134/2,130/3, Jeevan Nagar, Tathawade, Pune, Maharashtra - 411 033, India

*Corresponding author

\section{A B S T R A C T}

Keywords

Gerbera (Gerbera

jamesonii), Ecofrost,

Flowers

Article Info

Accepted:

18 September 2018

Available Online:

10 October 2018
Storage at $4^{\circ} \mathrm{C}$ with $95 \% \mathrm{RH}$ was evaluated as the best condition to maintain the shelf life of gerbera flowers of different varieties. Flower buds were packed in plastic bag and immersed in water, and then stored at ambient and also inside cold room of Ecofrost. Post storage life of gerbera decreased with increase in storage duration. The cold room stored flowers had shown post dry storage life 2.5 hours in ambient condition, even after taken out after 13 days of cold storage.

\section{Introduction}

The Gerbera (Gerbera jamesonii) is a member of the daisy family, and is also known as the Gerbera, African or Transvaal daisy. First encountered in South Africa, the Gerbera is also native to tropical regions in Asia and South America. All gerbera varieties have a central capitulum, which is composed of hundreds of individual flowers, surrounded by numerous florets creating the shape of a daisy. It is the most important commercially used $5^{\text {th }}$ cut flower in the world after Rose, Carnation, Chrysanthemum, and Tulip.

Gerbera is commercially available in two categories - Large Gebera, simply called 'gerbera' and Mini Gerbera, called 'germini'. Gerbera is available in diameters up to $12 \mathrm{~cm}$ and gernini up to $7 \mathrm{~cm}$ and are available in 100 's of varieties and colors (https://www.trianglenursery.co.uk/flowerguides/gerbera-guide).

Gerbera cut flowers are transported from field to market generally as a dry storage i.e. without holding in water.

During distant transportation, flowers loose its water percentage and turgidity, making them less attractive, loose market appearance and fetch low market rate.

Our objectives for this experiment are: To test 
the post storage life of Gerbera flowers (by dry method)

To check the vase life of Gerbera cut flowers under cold and ambient conditions (by wet method).

\section{Materials and Methods}

The present investigation entitled 'effect of cold storage on post storage life of Gerbera cut flowers at ambient conditions" was undertaken at Ecofrost Technologies Pvt. Ltd. Tathawade, Pune, Maharashtra under the supervision of Mr. D. B. More, Head of Customer Consulting Cell (CCC) department during first week of September, 2018.

Experiment was carried out at Ecofrost cold Room No. E011501A016. The climate of Tathawade, Pune was hot and semi-arid with the mean annual rainfall of $722 \mathrm{~mm}$, mostly received from $1^{\text {st } J u n e ~ t o ~} 15^{\text {th }}$ October (https://en.wikipedia.org/wiki/Pune).

Different gerbera cultivars with good commercial value in local market were selected for the present investigation. The selected flowers of different cultivars were harvested, when outer ray of disc florets was completely elongated and the outer two rows of disc florets were perpendicular to the flower stalk and having 45 to $60 \mathrm{~cm}$ of stem length.

The Gerbera varieties having yellow (Imperial), white (Dalma), orange (Dune) petal colors were brought to the Agricultural Laboratory of Ecofrost Technologies Pvt. Ltd, Tathawade from APMC flower market, Pune without mechanical damage and they were kept in clean water under ambient condition.

Total 100 flowers of Gerbera were brought, out of which 10 flower stems immersed in tap water and kept at ambient condition (photo 1).
Remaining 90 flowers were immersed in tap water and kept inside cold room condition ( $4^{\circ} \mathrm{C}$ with $93 \% \mathrm{RH}$ ) (photo 2 ).

The cut flowers were stored in bunches of 10 flowers/bunch. Individual flower buds were covered by plastic pocket closed at sepal side/stem side and open towards petal side. Each stem was given slanting cut of around $45^{\circ} \mathrm{C}$ at the end with sharp tool to ensure maximum contact area with water and reducing emboli or air bubbles.

Randomly 4 flowers were taken out each day from cold storage to ambient condition to check its post storage life with and without holding in water. Flowers were monitored after every an interval of thirty minutes.

After observing for 24, 48, 36\& 72 hours, in dry storage, flowers were again kept in water to check whether it recuperate its original turgidity and strength or not.

\section{Results and Discussion}

Fresh cut flowers took 12 hours to bend its neck and lose turgidity in ambient conditions.

Flower samples of different cultivars were taken out from cold room on day 1 , day 2 and day 3 and placed at ambient conditions where the moisture loss and symptoms of shriveling were seen, and it was observed that the neck started bending in 10.5, 9 and 8.5 hours; respectively.

On day 4 and day 7, flowers samples of different cultivars were taken out from cold room and placed under ambient condition (dry storage). It was observed to misplace its attractiveness and firmness in 7 hours and 5.5 hours; respectively.

Flowers sample of different varieties were taken out from cold room on day 5 to day 6 
and day 8 to day 9 and placed at ambient conditions, which resulted in dehydration of flowers within 6 and 5 hours; respectively.

Flowers samples were taken out from cold room on day 10 , day 11 to day 12 and day 13; which resulted in dehydration and bending its neck in 4, 3.5 and 2.5 hours at ambient conditions; respectively (Figure 1). Shelf life was measured as 4 days in vase treated flowers (holding in tap water) stored at ambient condition.

Within 10.5 to 2.5 hours, all flowers were observed to lose more than $25 \%$ moisture, turgidity and attractiveness and stem strength. Ray florets of flower become dull.

Flowers kept in water after 24 and 36 hours of dry storage regain its strength and turgidity within 8 and 12 hours; respectively.

Flowers after 48 to 72 hours of dry storage struggled to rehydrate.

Only 50\% of flowers were regained their turgidity and strength. The bacterial infections occurred only in the area submerged with water. Remaining portion of stem was found intact.

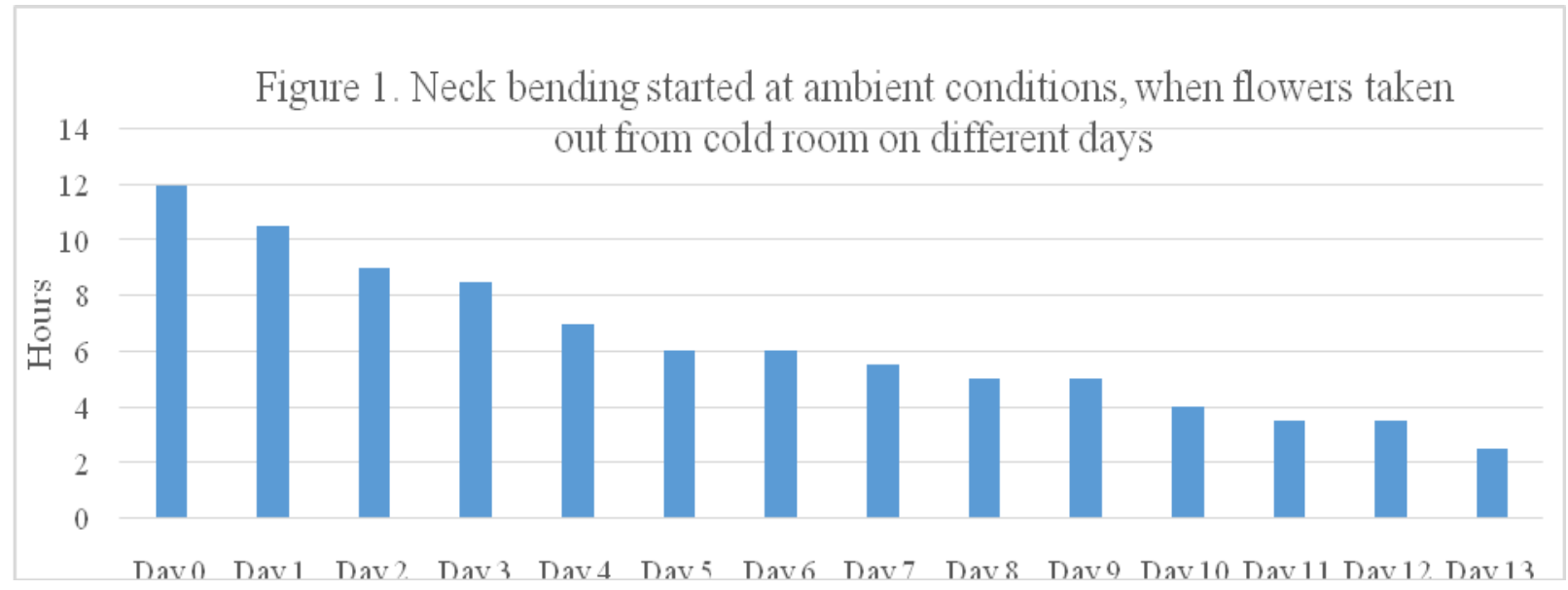

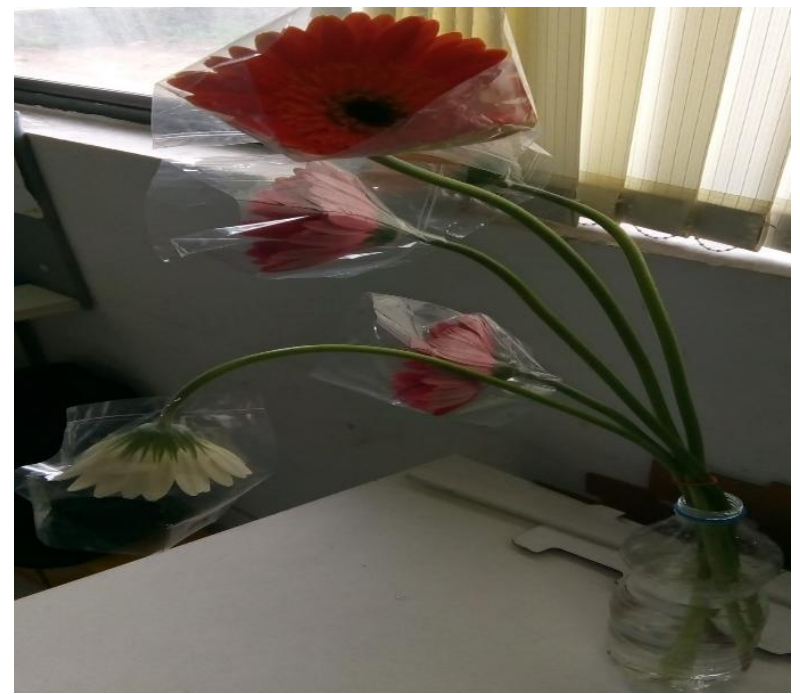

Photo.1 Gerbera flowers stored at ambient conditions

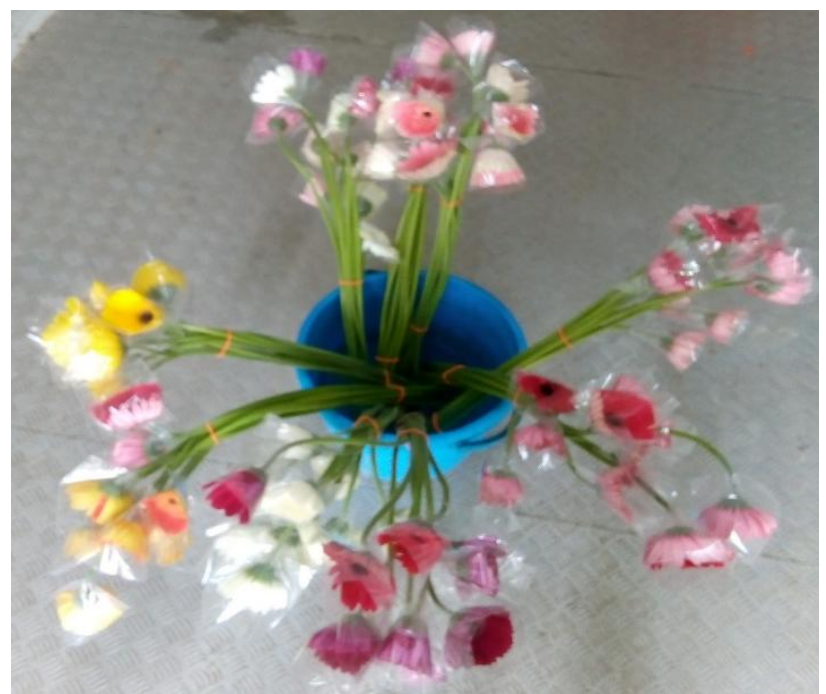

Photo.2 Gerbera flowers stored inside Ecofrost cold storage $\left(4^{\circ} \mathrm{C}\right.$ and $\left.93 \% \mathrm{RH}\right)$ 


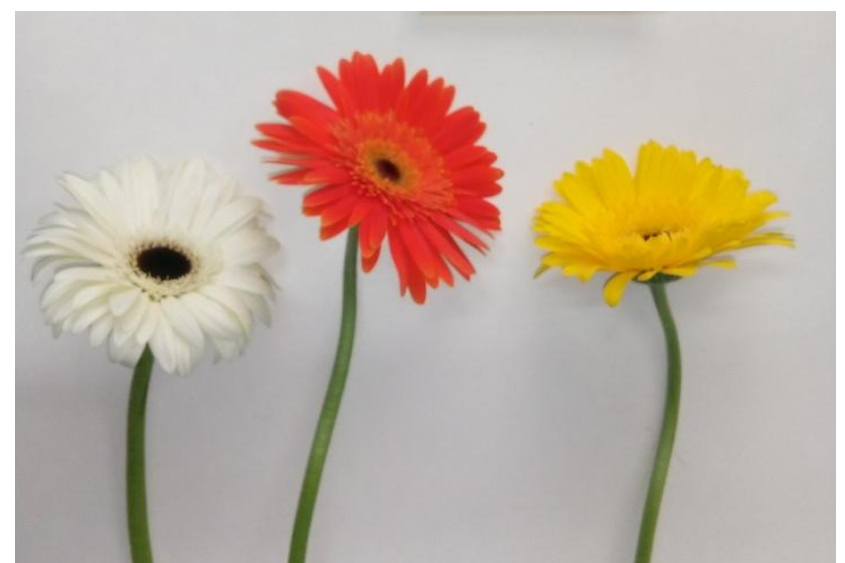

Photo.3 Gerbera flowers were taken out after 3 days from cold room and kept in dry storage (0 hour)

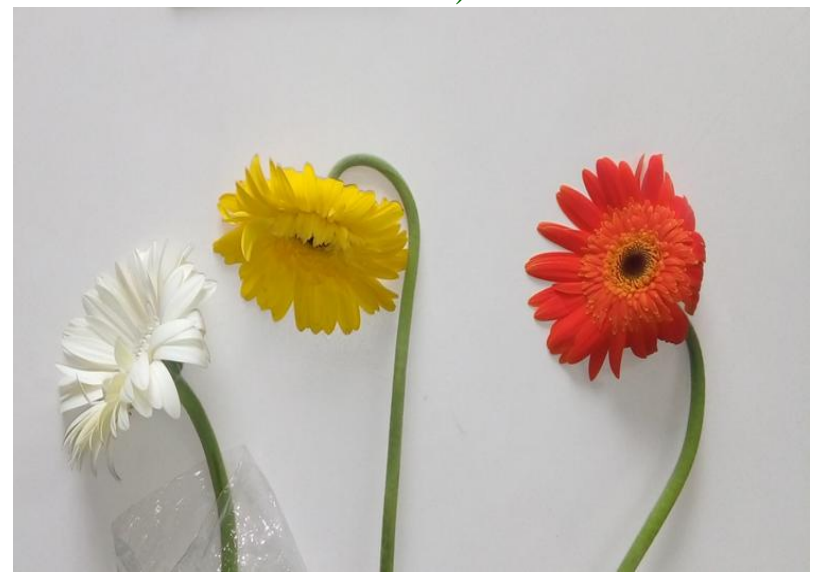

Photo.5 Gerbera flowers were taken out after 3 days from cold room and placed at ambient conditions ( 8 hours in dry storage)

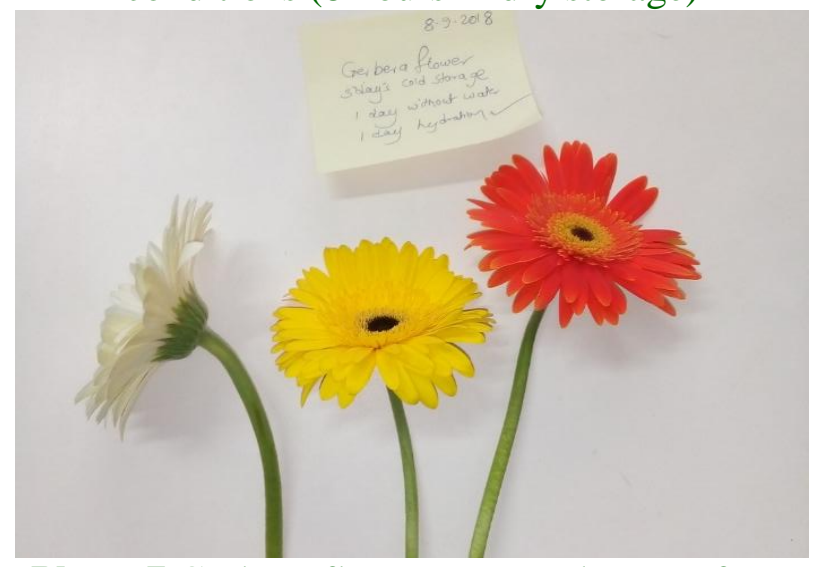

Photo.7 Gerbera flowers were taken out from cold room after 3 days and held in ambient conditions for 18 hours in dry storage and again held for 10 hours under water holding conditions

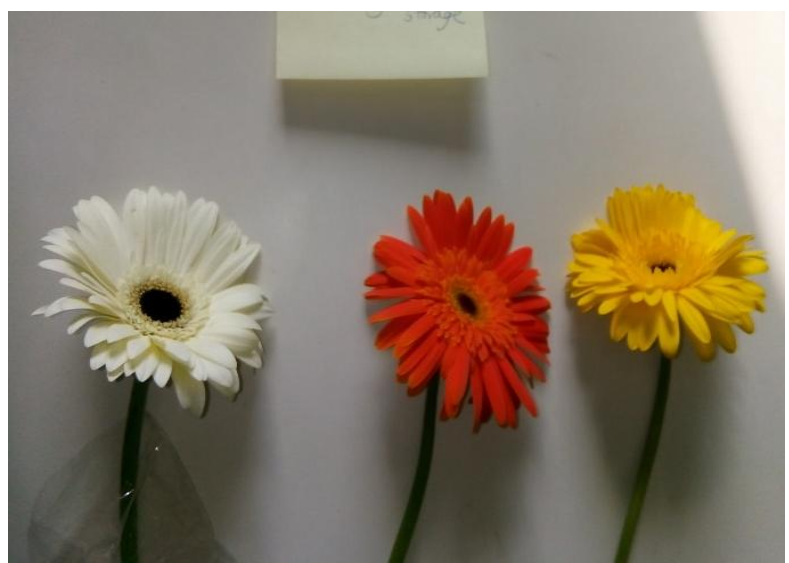

Photo.4 Gerbera flowers were taken out after 3 days of cold room and place in ambient conditions ( 3 hours in dry storage)

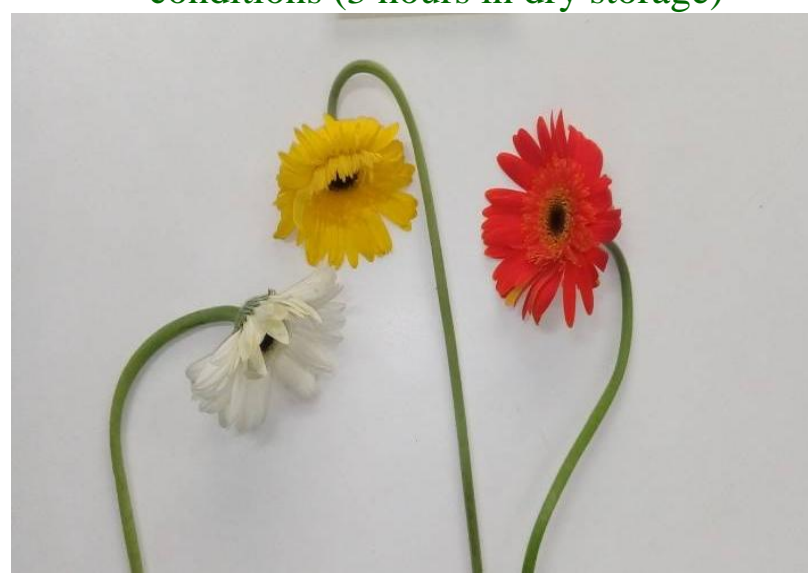

Photo.6 Gerbera flowers were taken out from cold room after 3 days and held at ambient conditions (12 hours in dry storage)

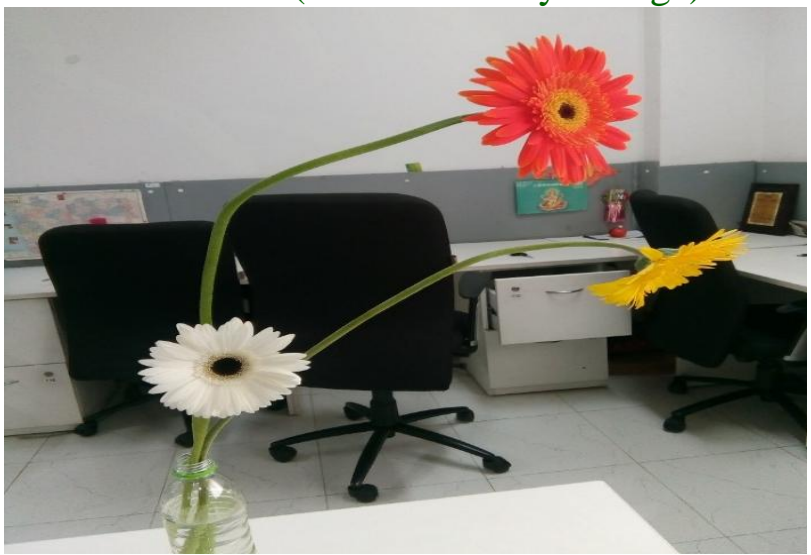

Photo.8 Gerbera flowers were taken out from cold room after 3 days and held in ambient conditions for 18 hours in dry storage and 10 hours for vase treatment (only water) 


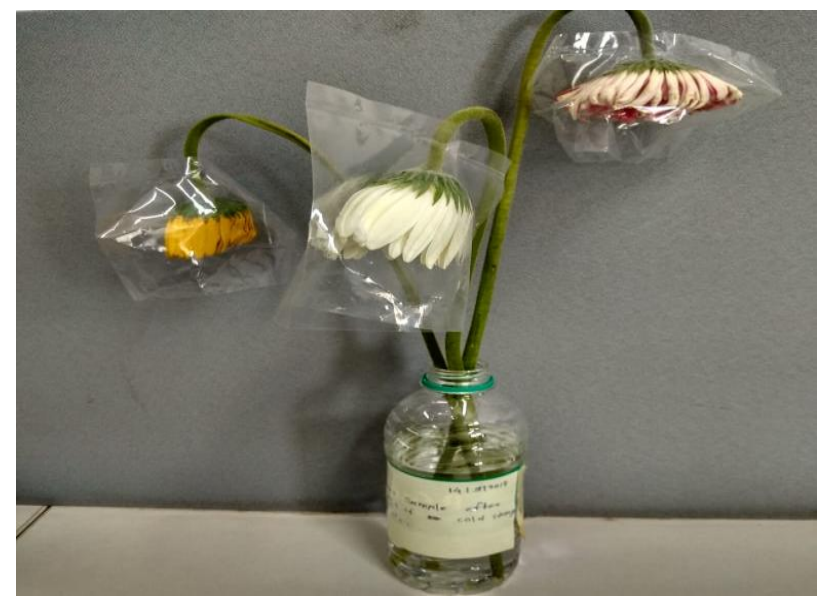

Photo.9

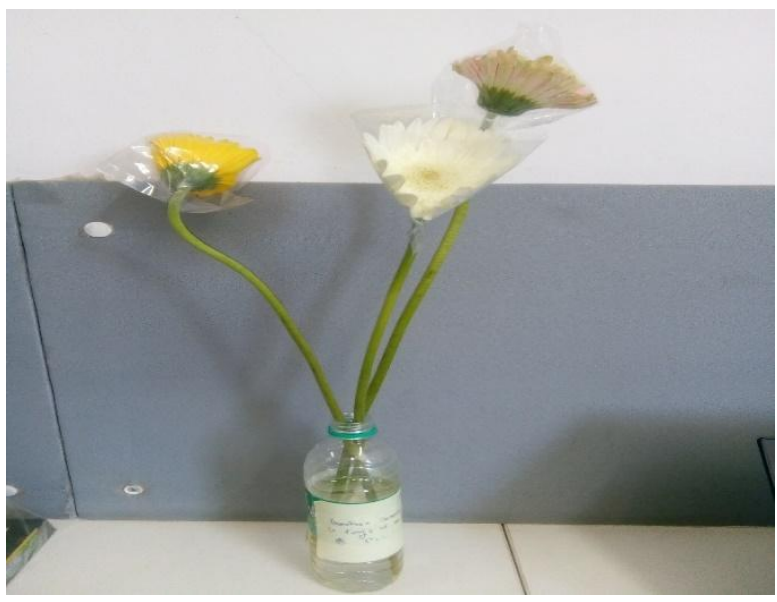

Photo.10

Gerbera flowers after 7 days of cold storage, 24 hours in dry storage $\& 18$ hours of hydration

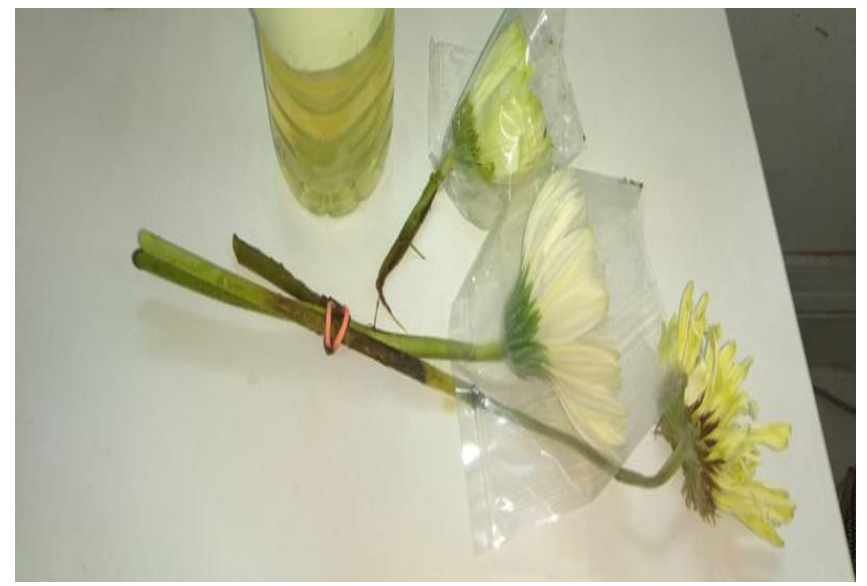

Photo.11 8 days old bacterial infected stem of gerbera flowers at ambient conditions

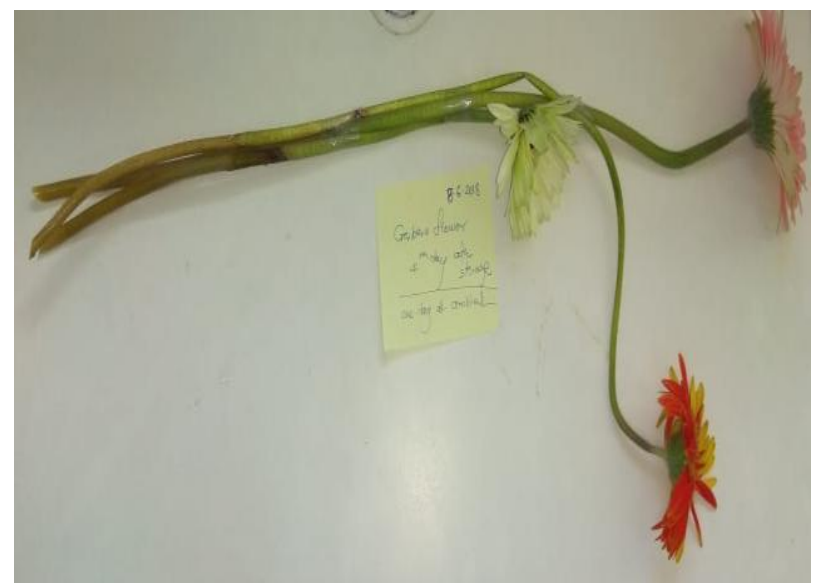

Photo.12 Bacterial infected stem of gerbera flowers after 5 days at ambient conditions

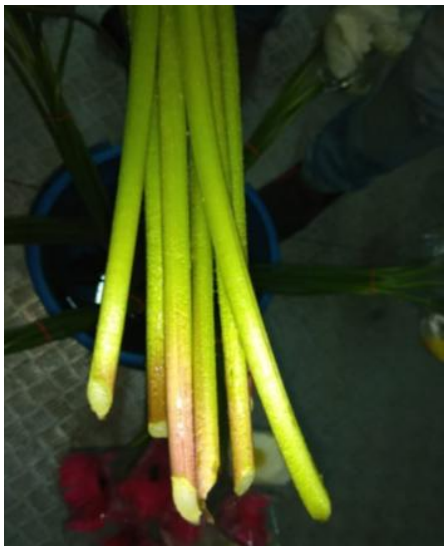

Photo.13 Healthy stems of gerbera flower after 13 days in cold storage $\left(4^{\circ} \mathrm{C}\right.$ and $\left.93 \% \mathrm{RH}\right)$ 
Cold stored flowers had shown good vase life, firmness and very less bacterial infections. Water retention of flowers was better in cold stored flowers than ambient stored flowers.

Very less deterioration in quality of Gerbera flowers was observed inside cold room upto initial fourteen days.

Gerbera flowers had 8 to 4 hours of dry post storage life at ambient conditions, reducing with increase in number of days flowers held inside cold room.

Flowers of different cultivars of gerbera were held at ambient conditions, which were susceptible to bacterial infection in stem (xylem) causing water imbalance in flower.

After 24 to 36 hours of dry storage, flowers were observed to regain its turgidity within 8 to 12 hours under hydration treatment.

Flowers beyond 48 to 72 hours of dry storage had more difficulty in regaining its original strength by absorbing water.
Cold stored flowers were less susceptible to bacterial infection as compared to flowers kept in ambient condition (photo 11 and 12).

Post storage life gerbera decreased with increase in storage duration.

The cold room stored flowers had shown post dry storage life 2.5 hours in ambient condition even after cold store period of 13 days.

\section{Acknowledgement}

Author thankful to the Director, Ecofrost Technologies Pvt. Ltd., Jeevan Nagar, Tathawade, Pune, Maharashtra, 411033 for providing excellent facilities for conducting this research. Financial assistance provided by the Ecofrost Technologies Pvt. Ltd. Pune, Maharashtra, India is highly appreciated.

\section{References}

https://en.wikipedia.org/wiki/Pune https://www.trianglenursery.co.uk/flowerguides/gerbera-guide

\section{How to cite this article:}

Mansute Ajinkya, P.B. Jadhav, D.B. More and Pokharkar, K.P. 2018. Effect of Cold Storage on Post Storage Life of Gerbera (Gerbera jamesonii) Cut Flowers at Ambient Conditions. Int.J.Curr.Microbiol.App.Sci. 7(10): 2382-2387. doi: https://doi.org/10.20546/ijcmas.2018.710.275 